University of Nebraska - Lincoln

DigitalCommons@University of Nebraska - Lincoln

6-1993

\title{
The Niche of the Gill Parasite Dactylogyrus banghami (Monogenea: Dactylogyridae) on Notropis stramineus (Pisces: Cyprinidae)
}

\author{
Jill A. Anderson \\ University of Nebraska - Lincoln \\ Kimberly J. Blazek \\ University of Nebraska - Lincoln \\ Tamara J. Percival Cook \\ Sam Houston State University, tcook@shsu.edu \\ John J. Janovy Jr. \\ University of Nebraska - Lincoln, jjanovy1@unl.edu
}

Follow this and additional works at: https://digitalcommons.unl.edu/bioscijanovy

Part of the Parasitology Commons

Anderson, Jill A.; Blazek, Kimberly J.; Percival Cook, Tamara J.; and Janovy, John J. Jr., "The Niche of the Gill Parasite Dactylogyrus banghami (Monogenea: Dactylogyridae) on Notropis stramineus (Pisces: Cyprinidae)" (1993). John Janovy Publications. 49.

https://digitalcommons.unl.edu/bioscijanovy/49

This Article is brought to you for free and open access by the Papers in the Biological Sciences at DigitalCommons@University of Nebraska - Lincoln. It has been accepted for inclusion in John Janovy Publications by an authorized administrator of DigitalCommons@University of Nebraska - Lincoln. 


\section{RESEARCH NOTES}

J. Parasitol., 79(3), 1993, p. 435-437

(c) American Society of Parasitologists 1993

\section{The Niche of the Gill Parasite Dactylogyrus banghami (Monogenea: Dactylogyridae) on Notropis stramineus (Pisces: Cyprinidae)}

Jill A. Anderson, Kimberly J. Blazek, T. J. Percival, and J. Janovy, Jr., School of Biological Sciences, University of Nebraska-Lincoln, Lincoln, Nebraska 68588-0118

\begin{abstract}
Distribution of the monogenean Dactylogyrus banghami on the gills of the fish Notropis stramineus (Cyprinidae) was described by calculation of mean relative positions and Levins' niche breadths on the linear spatial resource gradients gill filament length and gill arch length. Thirty fish with 276 worms were examined; only 1 of the fish had an additional gill parasite species (Trichodina $\mathrm{sp}$ ). Worms were more broadly and evenly distributed across the length of the gill arch than they were on the filament (breadths of 0.91 and 0.67 , respectively). Mean worm positions were near the center of both resources: $54 \%$ of the distance from the arch cartilage on the filament, and $54 \%$ from the ventral end of the arch itself. The results are considered consistent with predictions about the niche structures of species in unsaturated noninteractive specialist communities.
\end{abstract}

Most species of parasites are restricted not only to particular host species but also to sites on or in the host. Site specificity is often presumed to result from active site selection by the parasite (Holmes, 1973; Rohde, 1979, 1981). Site specificity in Monogenea has been studied by many workers and quantified in various ways that include counting worms in arbitrarily established zones such as regions of gills, gill arches, fins, or body surface; measurements of relative distances from gill arch cartilages; and use of nearest neighbor techniques (Hanek and Fernando, 1978; Ramasamy et al., 1985; Harris, 1988; Cone and Cusack, 1989; Janovy et al., 1991; Koskivaara et al., 1992). In the case of Salsuginus thalkeni, a parasite of the killifish Fundulus zebrinus, site specificity has been described by treating gill filament and arch lengths as resources in the Hutchinsonian model of a multi-dimensional ecological niche, then calculating the dimensions of the parasite's niche on these resources (Hutchinson, 1957; Janovy et al., 1991). Comparative data have not been published, however, that would reveal whether the distribution on spatial resources described for $S$. thalkeni, an ancyrocephalid, is similar to that of other monogeneans. The purpose of this study was to make such a comparison, using Dactylogyrus banghami on the gills of the minnow Notropis stramineus in the South Platte River of Nebraska.

Sand shiners, $N$. stramineus (Pisces: Cyprinidae), were collected from the South Platte River $5 \mathrm{~km}$ west of Roscoe, Nebraska, and taken to the Cedar Point Biological Station, $13 \mathrm{~km}$ north of Ogallala, Nebraska, for dissection. Thirty fish were examined during a 3-wk period from 13 June 1992 to 2 July 1992 . These fish were parasitized by $276 \mathrm{D}$. banghami.

Fish were processed according to the methods of Janovy et al. (1991). Each arch was removed, laid front face up in a sequence on a slide, and examined microscopically $(100 \times)$ for the presence of $D$. banghami. Magnification was reduced to $40 \times$ for the purpose of measuring worm positions on the filament and arch. The relative filament position for each parasite was determined by measuring the distance of the midhaptor from the gill arch cartilage, then measuring the length of the filament itself, using an ocular micrometer. The same procedure of measurement was made for the arch position, recording the distance of the worm from the ventral end of the arch, then measuring the arch length itself. The gills were then turned over, and the posterior face was examined in the same manner.

Measurement ratios that included filament position: filament length and arch position:arch length were converted into decimal fractions, multiplied by 10 , and then rounded to the nearest integer and summed for each unit. The summed data resulted in frequency distributions of worms on 2 linearly measured resources, filament length and arch length. Niche breadths on these resources were calculated according to Levins (1968), whose breadth index B takes into account both numbers of units in a resource set and evenness of a species' distribution among those units.

Mean filament and arch positions and variances were calculated, and frequency distributions of parasites on the linearly measured resources were tested for goodness of fit against 
TABLE I. Relative position and niche breadth of Dactylogyrus banghami on gill filaments and gill arches of Notropis stramineus.

\begin{tabular}{lccccc}
\hline & $\begin{array}{c}\text { Filament } \\
\text { position* } \\
\text { (variance) }\end{array}$ & $\begin{array}{c}\text { Breadth } \\
\text { on } \\
\text { filament } \dagger\end{array}$ & $\begin{array}{c}\text { Arch } \\
\text { position* } \\
\text { (variance) }\end{array}$ & $\begin{array}{c}\text { Breadth } \\
\text { on arch } \dagger \text { of worms }\end{array}$ \\
\hline All worms & $5.4(3.6)$ & 0.67 & $5.4(6.4)$ & 0.91 & 276 \\
Front face & $5.5(3.6)$ & 0.66 & $5.3(5.6)$ & 0.91 & 156 \\
Rear face & $5.4(3.6)$ & 0.67 & $5.5(7.5)$ & 0.94 & 120 \\
First arch & $5.5(3.8)$ & 0.64 & $5.1(7.6)$ & 0.94 & 70 \\
Second arch & $5.4(3.0)$ & 0.61 & $5.6(7.7)$ & 0.90 & 73 \\
Third arch & $5.4(3.9)$ & 0.67 & $5.5(4.3)$ & 0.70 & 80 \\
Fourth arch & $5.6(3.8)$ & 0.64 & $5.5(6.2)$ & 0.86 & 53 \\
\hline
\end{tabular}

* Relative position is the mean of the frequency distribution produced when filament or arch lengths are divided into 10ths; then the number of parasites occurring in each of these 10ths is plotted on the vertical axis, the 10ths being units on the horizontal axis.

$\dagger$ Breadth entries are niche breadths calculated according to Levins (1968) using the 10ths as units of a resource set.

discrete approximations of normal distributions by use of the chi-square statistic. Mean filament and arch positions were tested for differences using analysis of variance.

Distribution of $D$. banghami on the gill arches and mean positions and niche breadths on the gill arches and filaments for both front and rear arch faces are given in Table I. There was no statistical difference between the mean filament or mean arch position on any of the 4 arches or on either face. All parasite frequency distributions under all circumstances on the gill filaments were described accurately by a discrete approximation to the normal distribution. The observed circumstances on the arch positions were described best by a discrete approximation to the normal curve distribution; however, only the first, third, and fourth arch observed frequency distributions could be described accurately by the discrete approximation to the normal, when goodness of fit was tested using chi-square at a significance level of 0.05 . More worms were located on the front than on the rear arch faces, and this difference was significant at the 0.05 level when tested using the chi-square statistic.

Previous work on $D$. banghami has been limited to description, host specificity, and locality of parasite (see Hoffman, 1967). This paper is the first to describe quantitatively the niche of $D$. banghami on the gills of $N$. stramineus. The results indicate that as in the case of $S$. thalkeni, the niche of D. banghami on the gill filament is narrower than that on the arch (Table I). In comparison to $S$. thalkeni, $D$. banghami has a broader niche on the filament, a niche of identical breadth on the arch, but is located further out on the filament, on the average (cf. Table I and Janovy et al. [1991: table I]). Only 1 of the 30 fish in this study had other gill parasites, in this case protozoans of the genus Trichodina, so it was impossible to determine whether potential site competitors affected worm position and niche breadth. A much richer assemblage of gill parasites occurs on $F$. zebrinus than on N. stramin$e u s$, and these were shown to have no effect on worm position on the former host (Janovy et al., 1991).

The Hutchinsonian view of an ecological niche as a species-specific hypervolume defined by occupied regions of resource sets is a concept most meaningfully applied to the organisms whose resources are described easily by linear measurements, i.e., in terms of temperature, humidity, concentrations of certain compounds or elements, food particle size, flowing water speed, etc. Many parasite species, although quite site specific, occupy environments that are very difficult to describe in linear terms. It might be asked, for example, whether the various body surface regions of a fish are qualitatively, or quantitatively, different, and if they are to be treated as resources in the Hutchinsonian sense, where should measuring begin and what should be measured. Experimental work such as that of Harris (1988) and Cone and Cusack (1989) on Gyrodactylus species suggests that an anterior to posterior gradient exists along a fish's body. Thus it may be valid to consider body length a resource and segment occupied a dimension, but such consideration implies a biologically active component to the gradient, e.g., some compound or strength of current.

The problem of comparative resource description for parasites becomes more difficult when, for example, the difference between a cestode and a flea in/on the same host individual is considered. Each parasite occupies a distinct site, and, according to the Hutchinsonian definition, a species-specific ecological niche, but the identification and measurement of shared resources is exceedingly difficult. This illustration of the problem suggests that for parasites meaningful ecological comparison using the Hutchinsonian model might be confined to species that occupy different regions of an obvious gradient. In such cases, the definitions of fundamental and realized niches, i.e., dimensions on resources in the absence and presence of potential competitors, respectively, would be consistent with those used for freeliving organisms. The ultimate problem for ecol- 
ogists using host/parasite systems then becomes one of resource identification and measurement.

The authors acknowledge the use of Cedar Point Biological Station facilities and express appreciation to Darrell Thalken for use of private land near the collecting site.

\section{LITERATURE CITED}

CONE, D. K., AND R. CUSACK. 1989. Infrapopulation dispersal of Gyrodactylus colemanensis (Monogenea) on fry of Salmo gairdneri. Journal of Parasitology 75: 702-706.

Hanek, G., AND C. H. Fernando. 1978. Spatial distribution of gill parasites of Lepomis gibbosus (L.) and Ambloplites rupestris (Raf.). Canadian Journal of Zoology 56: 1235-1240.

Harris, P. D. 1988. Changes in the site specificity of Gyrodactylus turnbulli Harris, 1986 (Monogenea) during infections of individual guppies ( $P O e$ cilia reticulata Peters, 1859). Canadian Journal of Zoology 66: 2854-2857.

Hoffman, G. L. 1967. Parasites of North American freshwater fishes. University of California Press, Berkeley, $486 \mathrm{p}$.

Holmes, J. C. 1973. Site selection by parasitic helminths: Interspecific interactions, site segregation, and their importance to the development of helminth communities. Canadian Journal of Zoology 51: 333-347.

Hutchinson, G. E. 1957. Concluding remarks. Cold Spring Harbor Symposium on Quantitative Biology 22: 415-427.

JANOVY, J., JR., M. T. Ferdig, AND M. A. MCDowell. 1991. The niche of Salsuginus thalkeni, a gill parasite of Fundulus zebrinus. Journal of Parasitology 77: 697-702.

KoskivaAra, M., E. T. Valtonen, AND K.-M. Vuori. 1992. Microhabitat distribution and coexistence of Dactylogyris species (Monogenea) on the gills of the roach. Parasitology 104: 273-281.

LeviNS, R. 1968. Evolution in changing environments. Princeton University Press, Princeton, New Jersey, 120 p.

RAMASAMY, R., K. RAMALingam, R. E. B. HanNa, AND D. W. HutToN. 1985. Microhabitats of gill parasites (Monogenea and Copepoda) of teleosts (Scomberoides spp.). International Journal for Parasitology 15: 385-397.

RoHDE, K. 1979. A critical evaluation of intrinsic and extrinsic factors responsible for niche restriction in parasites. American Naturalist 114: 648671.

- 1981. Niche width of parasites in speciesrich and species-poor communities. Experientia 37: 359-361. 